Editorial: Documents and Tools

\author{
Ruth Bradley-St-Cyr
}

\begin{abstract}
This editorial, written by the new editor of the Papers of the Bibliographical Society of Canada, introduces a new thrust for the journal, that of publishing documents and tools that will be interesting and useful to the book studies community. The editorial also gives a brief overview of the papers in the current issue and themes for upcoming issues, as well as an overview of the editor's own research on The Ryerson Press and Ontario's Royal Commission on Book Publishing, which is the source of the feature document for this issue- "The Writers' Union Meets the Royal Commission”-as well as one of the tools, a table of contents of Royal Commission testimony. Patricia Demers's keynote speech from Congress 20I8, articles by Meaghan Scanlon and Richard Virr, and an index compiled by Cameron Anstee are featured in the issue.
\end{abstract}

\title{
Résumé
}

Cet éditorial, rédigé par la nouvelle rédactrice en chef des Cahiers de la Société bibliographique du Canada, donne une nouvelle impulsion à la revue, avec la publication de documents et d'outils que la communauté d'études sur le livre trouvera assurément intéressants et utiles. L'éditorial donne par ailleurs un petit aperçu des articles réunis dans le présent numéro et des sujets abordés dans les prochaines parutions. Il trace aussi un portrait de la recherche même de la rédactrice en chef sur The Ryerson Press et l'Ontario Royal Commission on Book Publishing, qui est la source du document vedette dans le présent numéro - "The Writers' Union Meets the Royal Commission" - et présente un des outils, une table des matières des témoignages de la Royal Commission. Figurent dans ce numéro le discours liminaire qu'a donné Patricia Demers au Congrès 20I8, les articles de Meaghan Scanlon et de Richard Virr, ainsi qu'un index élaboré par Cameron Anstee. 
As the new editor of the Papers of the Bibliographical Society, following Eli MacLaren's impressive 5-year term, I am very pleased that the first issue I am editing introduces a new thrust to our academic work: Documents and Tools. The purpose of this new, ongoing initiative, which adds to the variety of articles published in the journal, is to share useful tools (indexes, bibliographies, descriptions of archival or special collections, non-digital finding aids, etc.) and previously unpublished primary sources (documents or images) of interest to the book studies community. In this issue, Meaghan Scanlon offers us a tour of the Canadian comic book holdings at Library and Archives Canada, explaining the difference between the frequently confused John Bell Collection and Bell Features Collection, and reminding us not to forget the collection amassed via legal deposit. Richard Virr analyzes two documents that help illuminate the library of Edward Gibbon (1737-1794), author of The History of the Decline and Fall of the Roman Empire (1776-1788). Cameron Anstee provides an index of Nelson Ball's magazines Volume 63, Weed, and Hyphid, which sequentially ran from 1963 to 1968 . The index is a great boon to those looking to track down some of those ever-elusive periodical publications of such authors as Margaret Atwood, Earle Birney, bill bissett, George Bowering, Barbara Caruso, Victor Coleman, John Robert Colombo, Phyllis Gotlieb, Patrick Lane, Pat Lowther, Gwendolyn MacEwan, Seymour Mayne, David McFadden, bpNichol, Al Purdy, Miriam Waddington, and many others both well-known and unknown.

The keynote speech of Patricia Demers- "From Threshold, to Living Room, to Kitchen: On the Architectonics of Books" - given at the BSC conference in 2018 in Regina, Saskatchewan, opens this issue with a wonderful reminder of the joys of reading, even forespecially for-those of us who have chosen careers studying books rather than just loving them as we did as children. As academics, critics, librarians, and the like, we begin to read new, sometimes forgotten writers, enter into the conversation about them and, if we are lucky, work our way into the kitchen to discover how their texts are made. Or, as Demers puts it, we find ourselves on a journey "from curiosity, to revelation, to experimentation."

With this editorial, I also wanted to take the opportunity to introduce myself and my own book studies research to BSC members and PBSC 
readers and to say how extremely pleased I am to be taking on the stewardship of this journal that is as old as I am, both founded in 1962. After spending almost thirty years in book publishing myself, mostly as an editor, I've taken that base of knowledge and applied it to researching the publishers and cultural policy of this endlessly fascinating industry. While most of my English major colleagues study texts and authors, I study the structure that makes all of that possible-publishers. In other words, I'm interested in the factory and its business conditions, not so much in what the factory is producing, whether it be poetry or textbooks, or in its customers (a.k.a. readers). In many studies of authors and their readers or authors and their critical reception, publishers are seen as the people who "interfere" with authorial intent, often in an unjustified way, rather than the people who facilitate it. So I'm keenly interested in what draws people into publishing, and what makes them stay, since it is such a thankless business, and in Canada, intensely non-lucrative. When a publisher's work is done well, it is quite invisible, and the author gets all the credit anyway.

This interest is a natural outcome of these decades of work in the publishing industry. Often portrayed as a glamourous string of book launches hob-knobbing with the literati or long, intelligent discussions between author and editor hammering out the rough places in a manuscript (think Colin Firth as Max Perkins and Jude Law as Thomas Wolfe in the movie Genius) — publishing, or Canadian publishing at least, is rather a hard slog for survival in an unforgiving environment where the profit margin is razor thin but the authors complain about the size of their royalty cheques, the readers complain about the price of books, and the politicians complain that funding for publishers is going to "for-profit" businesses.

My PhD thesis looked at why the United Church of Canada sold The Ryerson Press in 1970 and my ongoing research looks at how that sale influenced the book publishing cultural policy that followed. The first step in crafting these new policies to help ensure the health of the industry was Ontario's Royal Commission on Book Publishing of 1971-1973, which resulted in two thoughtful and comprehensive volumes: the Background Papers (1972) and the report itself, Canadian Publishers and Canadian Publishing (1973). ${ }^{\mathrm{I}}$

I Both volumes were published by the Queen's Printer for Ontario. As well as these final reports, the commission also issued several important interim reports. The first was essentially a bailout of McClelland \& Stewart (23 March 
After the Canadian Centennial in 1967, the 1970s became a very fertile and hopeful time for Canadian publishing, for which the culturally wrenching sale of The Ryerson Press to McGraw-Hill, an American branch plant, was, ironically, the catalyst. ${ }^{2}$ Direct results of the November 1970 sale included the founding of the Association of Canadian Publishers and The Writers' Union of Canada, the bailout of McClelland \& Stewart, the establishment of grants for publishers at the Canada Council and the Ontario Arts Council, the expansion of the Ontario Media Development Corporation to include book publishers, and the passing of new laws to protect Canadian ownership and culture. The Royal Commission on Book Publishing, itself founded as a response to the sale, set much of this activity into motion. Because Ontario was the centre of Englishlanguage publishing in Canada, what happened in Ontario affected the entire publishing industry on a national scale.

Before the sale was finalized, The Ryerson Press had approached both the federal and provincial governments for help and had been ignored. There were those who thought that the press, owned by the United Church of Canada, should not be helped because they believed the church was rich or, since it did not have to pay business taxes, that it was already unfairly subsidized. There were also those who believed it didn't deserve help because the books it published were ugly, or not cutting edge enough. But many understood that the real value of the press was not necessarily in its poetry but in its

I97I) while the third extended this Ontario government loan program to other Canadian-owned book publishers (20 August 197I). The second (8 June 197I) and fourth (27 March 1972) reports dealt with problems in the distribution of paperbacks and periodicals, with the second interim report resulting in Bill 64 on ownership issues in order to curb the predatory activities of Metro News.

2 Ironically, almost fifty years after the sale, the educational publishing industry, including McGraw-Hill Ryerson, is crumbling under its own weight, the easy availability of educational material online, and the current educational exemption in the Canadian Copyright Act. One of the presentations at the joint Bibliographical Society of Canada/Canadian Association for the Study of Book Culture conference at Ryerson University in May 2017 ("Bound by Three Oceans: Reading, Writing, Printing \& Publishing in Canada since Confederation”) was by Clive Powell, Production Manager at McGraw-Hill Ryerson when I met him there in 1993, and then promoted in 1998 to Executive Vice President. His retirement project has been cataloging the 3000-title collection of Ryerson Press publications, contracts, and select author correspondence dating from I862 to 1970, which was transferred to McGraw-Hill with the sale of The Ryerson Press. This collection was donated to the library at Ryerson University in 2017. See his blog about this project at www.mychangingtimes.wordpress.com. 
textbooks, and that turning over control of one of the top educational publishers to Americans was a form of betrayal, especially since Ontario prided itself on its education system. Like the Press itself, Ontario's education system was founded by Egerton Ryerson. The furor about the sale reached a high point when author Graeme Gibson draped an American flag over the statue of Egerton Ryerson, which still stands on the campus of Ryerson University in Toronto, and led those assembled to protest in a chorus of "I'm a Yankee Doodle Dandy."

Having failed to help The Ryerson Press avoid the sale, the Ontario government did at least mount the Royal Commission to investigate the publishing landscape. The reasons why the United Church decided to sell The Ryerson Press were complicated. Some had to do with market conditions and some had to do with the internal workings of the United Church. ${ }^{3}$ The Royal Commission could not address internal church workings, of course, but they did try to deal with the market forces still threatening McClelland \& Stewart and other publishers. The first action, then, of the commission was to bail out McClelland \& Stewart (M\&S), which had also threatened to sell itself to the highest bidder. Their government subsidy - a forgivable loan-amounted to almost a million dollars. ${ }^{4}$

The commission was made up of three commissioners-lawyer Richard Rohmer, political strategist Dalton Camp, and publisher Marsh Jeanneret. Rohmer was the chair, but Jeanneret was definitely the brains of the commission; Rohmer characterizes him as an "extremely learned man" and "absolutely brilliant." Dalton Camp, Conservative political insider, sometimes seemed to be just along for the ride, though he did point the commission in the critical direction of investigating children's publishing. ${ }^{6}$ As the director of University of Toronto Press, Jeanneret was the only one of the three actually

3 These are all covered in my PhD dissertation, The Downfall of The Ryerson Press, available through the University of Ottawa library website: https://ruor.uottawa .ca/bitstream/I0393/31080/3/Bradley-St-Cyr_Ruth_20I4_thesis.pdf.

4 To read about M\&S's long-term legacy, see Kristine Smitka's book review of Elaine Dewar's The Handover: How Bigwigs and Bureaucrats Transferred Canada's Best Publisher and the Best Part of Our Literary Heritage to a Foreign Multinational, in PBSC 55, no. 2 (Fall 2017): 397-99.

5 Interview with Richard Rohmer, II October 2016.

6 As explained in my 2018 Congress presentation, "Ontario's Royal Commission on... Children's Literature?" (2018 Annual Meeting of the Bibliographical Society of Canada, The Book at the Crossroads of Diversities, 28-29 May 20I8, Regina, Saskatchewan). 
knowledgeable about the publishing industry. He was the one who asked the most intelligent questions and he was the one who poured himself into writing up the final report, much to the detriment of his own health. ${ }^{7}$ Whatever good came out of the commission is his legacy, though predictably Rohmer got the credit, even from people who should have known better.

The commission also had an executive secretary, Bob Fleming, assisted by Marc Couse, and a research staff headed by Sonja Sinclair, assisted by Gail McNaughton and Susan Keene. The commission accepted written briefs and heard testimony but also did its own research. Those who sent written briefs and were then asked to testify before the commission included everyone from the publishers of the day, like Anansi and Clarke Irwin, to a mother complaining about the lack of Canadian children's books, to the schoolchildren from London, Ontario, who wanted more Canadian content in their textbooks, to university professors. The commission researched, received submissions, and heard testimony on all aspects of Canadian publishing, providing important perspectives on what had gone wrong to cause the sale of the "mother" of all Canadian publishers, The Ryerson Press, or on the many other matters that could be improved in a book publishing industry in a vast country with a tiny population and two official languages, though the focus was almost entirely on the English side of the business. The questions that the commission investigated involved not just the impact of the sale, but also the forces - cultural, economic, political, public policy-that continue to shape the publishing business today.

Another of the commission's critical jobs was to deal with the infiltration of organized crime into the newsstand market, which included the distribution of magazines and mass market paperback books. Emergency legislation was hastily brought in to deal with the strong-arm tactics of the Molasky family, based in St. Louis, Missouri, in trying to buy up all the distribution territories in Southern Ontario,

7 Canadian Publishers and Canadian Publishing (1973), written largely by Jeanneret, was released on 22 February 1973 and Jeanneret was admitted to hospital for exhaustion soon afterwards. The Staff Notes section of the UTP newsletter of 7 September 1973 reported that Jeanneret would be on leave for an indefinite period and Eleanor Harman, Associate Director, would be in charge while he was gone. Jeanneret resigned from UTP in January 1977 at the age of 59, having had two bouts of ill health in the four years since the Royal Commission. He died at the age of 73. University of Toronto Archives, fonds Ai989-0009, University of Toronto Press, file Jeanneret, Marsh. 
which would have given them one of the biggest, most lucrative territories in North America had they been successful.

While the regular testimony to the commission was collegial and polite, the Molasky testimony was done in a more courtroom-like fashion, with lawyers and objections and mysterious memory lapses on the part of some witnesses, including 22-year-old Mark Molasky, answering for the family business. This is how I spent my summer holidays and my Tremaine Fellowship in 2016, immersing myself in this particularly unsavory testimony and trying to make sense of it all. Ultimately, the Molasky family was prevented from taking over the newsstand markets of Southern Ontario by the commissionsponsored emergency legislation (Bill 64) and was forced to sell off what they had already bought. Maclean-Hunter, which had been unsuccessful in its bid to buy The Ryerson Press, did manage to buy Metro News, the Toronto-based centre of the Molaskys' erstwhile Canadian empire.

Almost forgotten in all this testimony were the writers themselves. It wasn't until Farley Mowat bumped into Richard Rohmer at a party and demanded to know why the commission wasn't talking to writers - the probable answer being that the writers had not sent in a brief - that a day was set up for the authors to testify as a group. This was the fledgling Writer's Union of Canada, not officially formed yet. Rohmer's memoir, Generally Speaking, characterizes this meeting as dramatically blustery at first- thanks to Mowat pulling out a whiskey bottle with a flourish and placing it on the table-but cordial overall. ${ }^{8}$ Memory is a funny thing, though, and as you read the official transcript of the testimony, a completely different picture emerges - one of author after author speaking quite intelligently and rationally to the commission and then being systematically shot down by fellow author Hugh Garner, the proverbial skunk at the garden party. Things got so bad, in fact, that a group of authors-Margaret Atwood, Graeme Gibson, June Callwood, and Ian Adams—simply walked out. So delightful a read it is that we are making it the centrepiece of this issue. My eternal gratitude goes to the Archives of Ontario for permission to publish this testimony, which would not be out of place as a Fringe Festival play.

The final recommendations of the Royal Commission, written up by Jeanneret, were exemplary and comprehensive and although

8 Richard Rohmer, Generally Speaking: The Memoirs of Major-General Richard Rohmer (Toronto: Dundurn Press, 2004), 395. 
they were never quite taken up by the provincial government that founded and funded the commission, some action was taken at the federal level. This action included, most importantly, the initiation of grants to publishers, not just to authors, both at the Department of Canadian Heritage of the day and at the Canada Council for the Arts. As well, the Association for the Export of Canadian Books (now Livres Canada Books) was founded to assist with co-operative international marketing. And more stringent foreign ownership regulations were brought in.

Though Rohmer blames the fact that there was "no Deputy Minister who understood what we said or how to implement" it for the lack of immediate take-up in Ontario, the results of the commission's recommendations did filter back down from the federal to the provincial level, in part, thanks to the efforts of Robin Farr, the founding director of McGill University Press, who had worked at The Ryerson Press as editor-in-chief in the two years before the sale. He was one of The Ryerson Press staff who had approached the Ontario government seeking financial backing for an employee takeover bid that would have kept the press Canadian owned. After the sale, he then went to work at the Canada Council and brought in block grants for publishers and then moved to the Ontario Arts Council and brought in the half-back program, in which losing Lottario tickets could be used as coupons towards the purchase of Canadian books.

I am presently working on creating an accurate account of the impact of the Royal Commission and the cultural policy progress that it jumpstarted. The accounts currently available are those in the biographies and autobiographies of the three commissioners. Unfortunately, those of Rohmer ( 13 pages) and Camp (I page) are inaccurate and that of Jeanneret (8 pages) is not widely read, perhaps because of the ponderous title of his book, God and Mammon: Universities as Publishers. ${ }^{\text {IO }}$

In 2015, when I began researching the Ioo boxes of Royal Commission files at the Archives of Ontario, the only "finding aid" was a list of box titles. The archivist apologized that the files had never been properly organized and itemized, saying that no one had

9 Interview with Richard Rohmer, II October 2016.

Io Rohmer, Generally Speaking, 389-402; Geoffrey Stevens, The Player: The Life \& Times of Dalton Camp (Toronto: Key Porter Books, 2003), 252-53; Marsh Jeanneret, God and Mammon: Universities as Publishers (Toronto: Macmillan of Canada, 1989), 304-I2. 
ever really looked at them before, neither researcher nor archivist. I owe a great debt to my research assistant, Hien Lam, who is still patiently itemizing the contents of those Ioo boxes in order to create the missing finding aid, and whose spreadsheet now numbers well over a hundred pages. My research could not have progressed without him.

For my part, I have also created a table of contents of the official "blue books" of testimony (pictured on the front cover of this issue) given before the commissioners. This table of contents, which also appears in this issue, is quite a useful "mini finding aid" to the official Royal Commission material. The rest of the boxes include newspaper clippings, correspondence, research notes and documents, surveys, exhibits from some of the testimony, and so on. The testimony makes fascinating reading, especially in instances where a presenter says something like, "It would be really helpful to the industry if we had X..." and X is something that was actually implemented after the commission.

The part that The Ryerson Press played in this cultural policy progress is not as appreciated as it should be. Essentially, the sacrifice made by the church led to the resurrection of the Canadian publishing industry because of the policies recommended by the Royal Commission and taken up by the government. Almost fifty years later, it is time to re-evaluate that progress in order to make sure that our cultural policy is not backsliding but is still doing its job to protect our publishing industry and the authors and the literature that it supports.

My archival research, along with my interviews of commission chair Richard Rohmer, executive secretary Bob Fleming, other commission staff, and publishers who testified before the commission-such as Bill Clarke, Dennis Lee, and Jack Stoddart, Jr.- - is part of my book project on the impact of the sale of The Ryerson Press, planned to be published shortly after the $50^{\text {th }}$ anniversary of the sale in November 2020. Although we are still many months away from this important date in Canadian publishing history, it is not too early to share with you that the Fall 2020 issue of PBSC (Vol. 58, \#2) will focus on The Ryerson Press.

As well, the upcoming issue for 2019 (Vol. 57, \#I-2) focuses on LGBTQ+ Print in Canada: Overviews and Perspectives as well as a memorial section for William F.E. Morley, Francess Halpenny, and Greta Golick. We are still looking for contributions to the memorial section of short texts, reminiscences, and photos. Further down the road, special themes include Indigenous Publishing, Children's 
Literature, Reading through the Wars, and Editing, Designing, Sales: The People Who Work in Publishing. Calls for papers for some of these are included at the back of this issue for handy reference; the rest will follow in the next issue. We look forward to your contributions of articles, notes, documents, tools, book reviews, interviews, and photos. Of course, we always welcome articles on any topic, which can be uploaded to our Online Journal System (OJS), now in its new 3.I iteration, which is promised to be "a more intuitive navigation and customizable interface."

Besides written contributions to the journal, we are also looking for new volunteers to help produce it. We have openings for two new Assistant or Associate Editors-one French, one English-as well as translators and proofreaders (both languages). If you have experience and expertise to offer, we would very much welcome your assistance. If you are a grad student looking for experience, this is a great opportunity to be mentored in editing and producing a print publication by people who actually study these things. If you are interested, please email the editor, Ruth Bradley-St-Cyr: editor@ bsc-sbc.ca.

Thanks for reading!

\section{Editor Biography}

Ruth Bradley-St-Cyr is a writer, editor, and publisher with a PhD in English/Canadian Studies from the University of Ottawa. She has been the Director of University of Ottawa Press, Managing Editor of the United Church Publishing House, Publisher of Winding Trail Press, Production Manager of Stewart House Publishing, Associate Editor at McGraw-Hill Ryerson (School Division), Project Editor at Prentice-Hall Canada (College Division), Marketing Assistant at Stoddard Kids, and more. She is the only person since 1970 to work at both the United Church Publishing House and McGraw-Hill Ryerson. She is currently a freelance editor with her own company, Bradley-St-Cyr \& Associates, and a part-time professor at the University of Ottawa. 


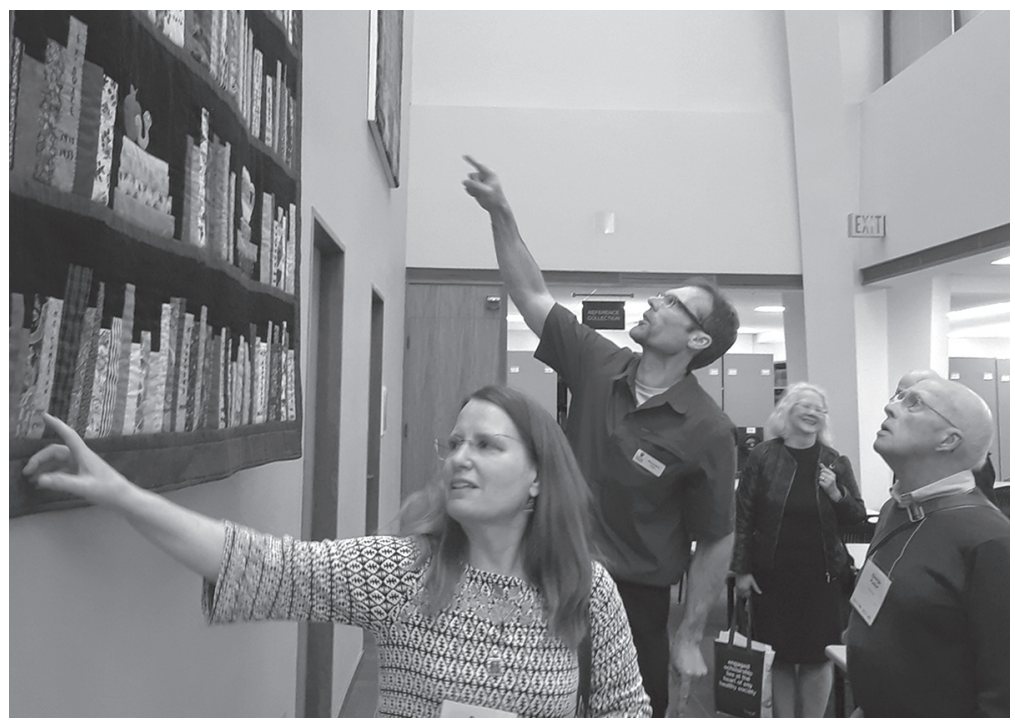

Collections Development Librarian/BSC Local Arrangement Convenor Michael Shires (centre) shows members of the Bibliographical Society of Canada around Archives and Special Collections in University of Regina's Dr. John Archer Library on 28 May 2018. Left to right: Susan Cameron, Michael Shires, Karen Smith, George Parker, and possibly Peter McNally behind George. (Photo by Ruth-Ellen St. Onge) 